\title{
DONA MARIA BAIA: UMA ESCRITORA DE SI
}

\author{
Dona Maria Baia: a writer of yourself
}

\author{
José Luiz da Silva Lima \\ (D) https://orcid.org/0000-0002-5393-5913 \\ Jailma dos Santos Pedreira Moreira
}

\author{
https://orcid.org/0000-0002-6201-1499 \\ Universidade do Estado da Bahia, Programa de Pós-graduação em Crítica Cultural, \\ Alagoinhas, BA, Brasil. 48000-000 - sec.poscritica@gmail.com
}

\begin{abstract}
Resumo: Esta proposta adentra no universo da cultura popular, das narrativas e poéticas orais, apresentando uma personagem com uma potência criadora singular: Maria José Dantas das Mercês, Dona Maria Baia, sexagenária, agricultora, residente no Assentamento Rose de Santa Luz-BA e detentora de um modo de produção artístico-cultural que apresenta escrituras, "escrevências e feituras" de poesias, letras de música, contos, artesanatos e culinária alternativa. Objetiva-se mostrar como os (a)fazeres poéticos desta personagem, em específico os cânticos e cantorias, ajudaram a produzir outras subjetividades para si e para outras mulheres, interferindo no coletivo comunitário. Metodologicamente, estamos empreendendo uma análise e exploração documental, a partir de acervos institucionais cedidos para a pesquisa, os quais aliamos aos estudos da literatura e cultura popular pela via da crítica cultural, levando em conta uma perspectiva autobiográfica, os estudos de gênero, de subjetividades e de feminismos. As poéticas, escrituras e performances socioculturais desta personagem tem favorecido uma desconstrução de uma identidade prescrita para ela e outras mulheres, desencadeando outros modos de vida e outra percepção de si, que se desenha como resistência às condições adversas de subalternidade em seu habitat social e ao patriarcado e suas interseccionalidades.
\end{abstract}

Palavras-chave: Mulher Agricultora. Subjetividades. Resistências.

Abstract: This proposal enters the universe of popular culture, narratives and oral poetry, presenting a character with a unique creative power: Maria José Dantas das Mercês, Dona Maria Baia. Sexagenarian, farmer, resident in the Rose settlement of Santa Luz-BA. Owner of an artistic-cultural mode of production that presents scriptures, "scribbles and plays" of poetry, lyrics, short stories, crafts and alternative cooking. It aims to show how the poetic works of this character, in particular the songs and songs, helped to produce other subjectivities for themselves and for other women, interfering in the community collective. Methodologically, we are undertaking an analysis and documentary exploration, from institutional collections assigned to research, we combine studies of literature and popular culture and cultural criticism, taking into account an autobiographical perspective, studies of gender, subjectivities and feminisms. The poetic, scriptural and sociocultural performances of this character has favored a deconstruction of an identity prescribed for her and other women. It suggests other ways of

Esta obra está licenciada sob uma Creative Commons - Atribuição 4.0 
life and another perception of self, which is designed as resistance to the adverse conditions of subalternity in its social habitat and against patriarchy and its intersectionalities.

Keywords: Woman farmer. Subjectivities. Resistances.

\section{Muito prazer, eu sou Maria Baia!}

"Eu me sentia muito minúscula, eu me sentia uma pessoa... atrás de todo mundo... Eu me sentia rejeitada, por mim mesma. Eu achava que todo mundo estava na minha frente, eu era sempre atrás de todo mundo..." (MERCES, 2017b).

$\mathrm{Na}$ esteira desta fala preliminar e mobilizadora de Maria José Dantas das Mercês ou simplesmente, dona Maria Baia, vamos explorar aspectos de um passado, não tão distante, que foram se transformando e se (re)configurando em outras impressões e sentimentos autoperceptivos. De imediato, questões que estimulam uma reflexão: quem fala isso de si? Por que fala? Qual o seu lugar de fala e quais lutas travou na sua trajetória para que possa fazer essa (re)leitura do passado-presente? Quais as potências (re)descobertas dessa mulher que transformaram sua vida?

Nosso ponto de largada está subscrito a disponibilização de um arcabouço iconográfico desta mulher, cedido pelo IMAQ - Instituto Maria Quitéria ${ }^{1}$, no qual buscamos delinear um trabalho discursivo ancorado em uma metodologia em uma análise exploratória destes arquivos documentais disponibilizados pelo Instituto. Com isso, consubstanciaremos estudos da literatura e cultura popular e através da crítica cultural, levando em conta uma perspectiva autobiográfica, os estudos de gênero, de subjetividades e de feminismos. Vislumbramos mostrar como os (a)fazeres poéticos desta personagem, em específico as cantigas alinhadas à produção culinária que desenvolve, ajudaram a produzir outras subjetividades para si e para outras mulheres, interferindo em suas vidas e no coletivo comunitário.

Voltando o foco para a fala inicial de Dona Maria Baia, possivelmente, podemos inferir um sentimento de "menos valia," sobre o qual sua autoimagem pode traduzir uma possível evidência da negação de si, da autopercepção do Self ${ }^{2}$ que, segundo Jung (1991), trata-se do "arquétipo ${ }^{3}$ da ordem e totalidade", abrangendo o consciente e o inconsciente", sendo polares, mas não opostos, com uma relação de complementaridade que, particularmente, tem no Self o mediador e gestor dos recursos e dos conteúdos supra e intrapessoais do individuo. Ainda segundo Jung, a personalidade se dá a partir de um núcleo, um centro, que é responsável pelo desenvolvimento da mesma, ou seja, não é apenas o Self o ponto central, mas ele engloba a

\footnotetext{
${ }^{1}$ Instituto Maria Quitéria - IMAQ, entidade do $3^{\circ}$ setor fundada em 1998 que está sediada na cidade de Feira de Santana-BA, e que empreende projetos socio-comunitários com foco na cultura, esporte, educação e mobilização de comunidades carentes local e em mais 2 cidades da região sisaleira, no semiárido da Bahia.

${ }^{2}$ Jung chamou o Self de arquétipo central, arquétipo da ordem e totalidade da personalidade. O Self representa o anseio humano de unidade. Esse arquétipo expressa-se por meio de diversos símbolos e o principal deles é a mandala. O Self é o princípio organizador de toda a psique e, tanto é verdade, que o ego é um complexo cujo núcleo é o Self (JUNG, 2011).

${ }^{3}$ Os arquétipos são um conjunto de imagens e representações sociais, originadas de uma repetição progressiva de uma mesma experiência, durante muitas gerações, que dão significado. Sábios; santos; mitos; lendas; seres alados e sobrenaturais; pai; mãe; amor; felicidade, sabedoria e uma infinidade de representações sociais compõem o universo dos arquétipos (JUNG, 2011).
}

Anu. Lit., Florianópolis, v. 24, n. 1, p. 52-69, 2019. ISSNe 2175-7917 
totalidade (JUNG, 1991).

Dona Maria Baia encena um foco compatível com "esse não se perceber em si e de si", enquanto um sujeito de possibilidades, distorcendo sua autoimagem, colocando sobre si uma espécie de "véu de menos valia", vinculado a pressupostos e suposições projetados por ela, em relação a comparativos que faz com outros elementos, com as quais ela não está, a priori, contemplada. São modelos idealizados e introjetados, (in)conscientemente, de querer ser uma outra, uma mulher "melhor" que, aos poucos, foi se transformando com o decorrer do tempo, a partir das interações com o outro, fazendo emergir um ser que, hoje, já se reconhece como de potências; uma autora; escritora; compositora; intérprete; culinarista; artesã; líder comunitária enfim, uma escritora e autora de si.

É importante compreender um pouco quem é essa personagem em questão, conhecendo um pouco da sua biografia que, ao nosso modo de ver, representa muito da sua construção enquanto mulher, ativista cultural e liderança comunitária. Seu nome Maria José Dantas das Mercês ou Dona Maria Baia, como se envaidece, se reconhece e orgulha-se ao falar: "Maria Baia, é esse o meu nome artístico (sic)," que, segundo ela, é "reconhecida". Crê ser um diferencial que a distingue no que hoje ela está realizando, tendo em vista que é bem incomum esse pseudônimo, que se configura como uma "marca registrada," que foi moldando e ganhou mais notoriedade a partir de um despertar artístico-cultural da mesma.

Sobre o nome inclusive, perguntamos a ela, o que a fez viajar em suas memórias de infância, trazendo imagens, cheiros e sons que reavivam a lembrança do seu avô materno, o qual ela afirma que fora o autor do seu apelido.

O meu nome de Maria Baia, vem desde eu pequenininha, eu era bem gordinha, né? Sentada lá no chão... ai meu avô dizia: Ôh! Minha baiana! Ai ficava, minha baiana vem, minha baiana vai! E por isso ficaram me chamando de Maria Baia! Desde pequenininha! Ai hoje, e eu fico muito feliz. (risos...) lembro do avô, lembro da avó, lembro da família toda! É uma marca... (risos...). (MERCÊS, 2017a).

Nascida na Fazenda Serra do Pintado no município da Valente, região sisaleira da Bahia, Maria Baia é a 6 a do casal João Dantas de Ataíde e Terezinha de Jesus Silva que, dos 25 filhos 4 estão vivos, o último morreu aos 33 anos e os outros ainda muitos novos, devido a problemas de saúde comuns à época e que eram difíceis de tratar ou buscar recursos para tratamento, devido a precariedade do sistema de saúde e condições da família. Sua avó materna foi sua parteira, trazendo-a ao mundo em 28 de outubro de 1955. Ao sexto mês de vida um susto: a pequena Maria tomou um chá de sabugueiro ${ }^{4}$ para combater um problema de saúde, e, por conta de uma reação adversa, como acredita e conta, "foi dada como morta" e até foi velada por uma manhã. Contudo, voltou a si, recuperou-se do susto, e seguiu sua vida com muita dificuldade,

\footnotetext{
${ }^{4} \mathrm{O}$ sabugueiro, de nome científico Sambucus nigra, é uma espécie arbustiva pertencente ao gênero Sambucus da família Adoxacea. Dentre muitas propriedades, "é uma excelente fonte de flavonoides, vitamina C, e propriedades antibacterianas e antivirais: que estimulam o funcionamento do sistema imunológico e ajudam a aliviar algumas alergias". Disponivel em: http://www.mundoboaforma.com.br/cha-de-sabugueiro-para-que-serve-como-fazer-ebeneficios/\#ghmg486AdzLWRoiB. Acesso em: 02/08/2019.
}

Anu. Lit., Florianópolis, v. 24, n. 1, p. 52-69, 2019. ISSNe 2175-7917 
como é típico de crianças que vivem historicamente em estado de vulnerabilidade social, no sertão nordestino.

Com muitas outras intercorrências de saúde, a menina Baia sobreviveu para poder percorrer e explorar a caatinga e serras da fazenda onde nasceu e, ao mesmo tempo, (con)viver com vários outros personagens do cotidiano sertanejo. Seu ímpeto de curiosidade e vivacidade, era, por vezes, contido por seu pai João que, segundo ela, “era muito amoroso, mas rígido e controlava muito nóis." (MERCÊS, 2017a). A partir desta fala e na continuidade da narrativa de Baia, é possível identificar e deduzir que este controle imposto à jovem Baia, sempre foi mais rígido para jovens mulheres sertanejas.

Contudo, Baia sempre foi curiosa e ávida por desafios e tinha na sua inquietude, com lampejos transgressores, um ímpeto que a impelia para o mundo imagético e místico que habita o universo no qual ela estava imersa. Encanta-se, desde de cedo, com a áurea mística que envolvia as benzedeiras e as comemorações festivas ligadas à tradição religiosa católica, assim como também se encantava com outros eventos não necessariamente ligados a celebração religiosa, tais como: bata de feijão e milho; boi roubado; samba de roda; rodas de ciranda, contação de causos e lendas entre outros. Ao que parece, boa parte da sua memória individual foi "povoada", formada e sugestionada a partir deste contato coletivo, de interação com estes grupos, que promoviam tais rituais.

Considerando este aspecto de "povoamento da memória" por lembranças da infância, Maurice Halbwachs afirma que a memória individual é construída a partir de uma memória de grupo, formada no interior de uma coletividade, por suas experiências dispostas, com as quais o sujeito partilha e experimenta vários sentimentos, reflexões, paixões, ideias, percepções das referências e lembranças próprias do grupo (HALBWACHS, 1990). Deste ponto de vista de Halbwachs é possível perceber na narrativa de Baia a importância e presença do grupo, de uma coletividade, das mestras de tradição oral em sua infância, com seus (a)fazeres e mestrias interferindo na formação das suas lembranças e memórias, o que, certamente, a inspirou e a motivou nos seus (a)fazeres criativos, dando continuidade ao que fora aprendido com esta tradição oral.

Houve uma mudança drástica em sua vida quando, aos 13 anos, teve que mudar para Feira de Santana, um grande centro urbano, onde voltou aos estudos na Escola Municipal Wilson Falcão, matriculando-se na $5^{\mathrm{a}}$ série e terminando o chamado ginasial, ou a $8^{\mathrm{a}}$ série. Aos 18 anos, ela retorna para sua casa na fazenda Serra do Pintado e já nesta época mantinha um namoro com um jovem da região, chamado Izael das Mercês, mais conhecido como Zai. Este viria a ser seu futuro esposo no ano de 1974, ela, então, com 19 anos de idade. Pouco tempo depois engravida e tem sua primeira filha. Mesmo com os tantos afazeres que envolvem o matrimônio, ela aprende corte e costura através de um curso por correspondência ${ }^{5}$, vindo depois a costurar

\footnotetext{
${ }^{5}$ Os cursos por correspondência, praticamente em desuso em tempos de internet, já tiveram seus dias de glória. Estudos do Ipea (Instituto de Pesquisa Econômica Aplicada) mostram que pouco antes de 1900 já existiam propagandas de cursos profissionalizantes por correspondência em jornais do Rio de Janeiro. Nos anos 1940, com a popularização do rádio, os alunos aprendiam uma profissão (eletroeletrônica, corte e costura, eletricidade, mecânica etc.) estudando em casa, onde recebiam o material didático pelos Correios.
}

Anu. Lit., Florianópolis, v. 24, n. 1, p. 52-69, 2019. ISSNe 2175-7917 
para a família e para outros interessados. Com Izael, o Zai, Baia tem 14 filhos, destes, 10 sobreviveram.

Iniciada por sua avó como ajudante da mesma no seu oficio de parteira, em 1977, Maria Baia matricula-se em um curso de técnicas de enfermagem, no sentido de aprofundar e refinar seus conhecimentos repassados por sua avó. Este curso profissionalizante continuado, com estágios aos finais de semana, lhe permitiu uma desenvoltura melhor na prática de parteira, a qual exercia morando no então povoado denominado Varginha, onde também atuava como professora leiga. Tempos depois vai trabalhar no hospital José Mota Araújo, na cidade de Valente e, mais tarde, no Hospital Regional na cidade de Serrinha. Sobre o oficio de parteira ela afirma: “... peguei alguns meninos, eu tenho na faixa de uns trinta e poucos meninos, passados por minha mão” (MERCÊS, 2017a).

Dando um salto no tempo, em 1989 ocorreu uma grande reviravolta em sua vida, pois vai com seu esposo, seus filhos e várias outras famílias participar de um movimento, orientado por Sindicatos locais, para ocupação e reivindicação de posse da Fazenda Lagoa do Boi, a 6 Km do centro da cidade de Santa Luz. Esse Movimento, que durou 3 anos, foi permeado por muitos embates entre os camponeses, que reivindicavam a terra, e as agências de controle social e o poder hegemônico local. De posse da terra em 10.07.1992, instala-se o Assentamento da Lagoa do Boi que, informalmente, por seus moradores, foi rebatizado como Assentamento do Rose, em homenagem a uma integrante do Movimento dos Sem Terra (MST), ${ }^{6}$ conhecida como Roseli Celeste Nunes da Silva, líder camponesa que morreu em um conflito de terra, logo no início nos anos 80, no Rio Grande do Sul.

Em 2005, dona Maria Baia passa a integrar o movimento de incursões socioculturais do Ponto de Cultura Expressões Sertanejas ${ }^{7}$ que foi empreendido pelo Instituto Maria Quitéria (IMAQ) e que deu origem a vários outros projetos institucionais. Este Ponto de Cultura estimulou e mobilizou, em 2009, 10 mulheres, lideradas por Dona Maria Baia, a conceber e fundar o Grupo de Cantorias Rosas Vivas. Em 2010 o movimento de mulheres grava seu primeiro CD com 15 músicas autorais e, neste mesmo ano, Dona Maria Baia lança seu $1^{\circ}$ livro: Cabeça de frade faz doce: As cantigas e a culinária de Dona Maria Baia, pelo selo IMAQ Edições (2010), no qual podemos encontrar suas primeiras composições musicais e receitas da culinária alternativa, que tem tido uma circulação regional significativa. Atualmente o Grupo Rosas Vivas tem sido convidado para eventos, encontros regionais da agricultura familiar, festas e shows, através dos quais recebe cachês por suas apresentações. Desde então, Dona Maria não para de produzir e se (re)inventar!

\footnotetext{
${ }^{6} \mathrm{Em}$ 1984, os trabalhadores rurais que protagonizavam essas lutas pela democracia da terra e da sociedade se convergem no $1^{\circ}$ Encontro Nacional, em Cascavel, no Paraná. Ali, decidem fundar um movimento camponês nacional, o MST, com três objetivos principais: lutar pela terra, lutar pela reforma agrária e lutar por mudanças sociais no país.

${ }^{7}$ O Programa sociocultural concebido e desenvolvido pelo IMAQ- Instituto Maria Quitéria, foi empreendido a partir das incursões comunitárias da entidade em comunidades urbanas, periféricas e rurais. O Expressões Sertanejas foi apoiado e conveniado ao Programa Cultura Viva - Ministério da Cultura / MinC / Governo Federal do Brasil, entre os anos de 2005 a 2010.
}

Anu. Lit., Florianópolis, v. 24, n. 1, p. 52-69, 2019. ISSNe 2175-7917 


\section{Uma rosa viva e suas percepções e enfrentamentos}

A autoimagem evidenciada no pensamento inicial da nossa personagem central: “[...] Eu me sentia muito minúscula, eu me sentia uma pessoa... atrás de todo mundo... Eu me sentia rejeitada, de por mim mesma. Eu achava que todo mundo estava na minha frente, eu era sempre atrás...” (MERCÊS, 2017b), instiga-nos a adentrar na trajetória de Maria José Dantas das Mercês, dona Maria Baia, e identificar algumas das suas inquietações e motivações na busca (in)consciente do seu "self verdadeiro self", um eu espontâneo, singularizado.

Para Winnicott (1983), o "verdadeiro self" eclode logo que haja alguma organização psíquica na pessoa e, assim, estabelece que o conceito de "verdadeiro self" remeteria aos rudimentos - antes de haver uma separação entre interior e exterior - do que posteriormente constitui a realidade interna da criança. Complementa, descrevendo que o que se chama de "verdadeiro self" tem como referência o gesto espontâneo da criança, que pode ser traduzido por uma gama de expressões criativas apresentadas no início da vida desta criança e, que a possibilidade de se" ter uma "mãe suficientemente boa", oportunizaria a possibilidade de buscar, em certa medida, uma adaptação a estes "gestos" a partir de sua sensibilidade aos movimentos (físicos e afetivos) da criança (WINNICOTT, 1983).

O conjunto descritivo biográfico de Dona Maria Baia sugere que há essa possibilidade de busca e retomada desta essência criadora e criativa, deste "verdadeiro eu de potências", que pode ter sido reprimido com o tempo, haja vista a sua autopercepção de desvalia na fala inicial, que teve, com o passar dos anos, uma transformação substancial que foi reconfigurando um outro ser; no avivamento do "verdadeiro self", deste eu singularizado e amplo. Um olhar sobre sua iconografia subscrita na sua produção textual e sobre suas performances artístico-cultural, também nos leva a deduzir que há a busca de e por um lugar de fala, de posicionamento e posições, que visam demarcar um território que se contrapõe aos interditos e silenciamentos impostos ao ser feminino, sob a égide do patriarcado, que estabelece impeditivos ao discurso feminista.

Nas letras da nossa personagem existe um enunciado que propõe um tornar-se um "ser outra", evidenciando uma reinscrição e uma revelação transformadora, que indica a possibilidade de não ser subalterna e subserviente ao patriarcado. Essa escrita de vida de dona Maria Baia propõe uma ruptura das convenções e convencimentos implícitos e explícitos, os quais impõem condições precarizadas, negam direitos, e subalternizam a escrita feminina no sentido de tentar apagar sua potência, interditar o discurso feminino libertário.

"Sai da cozinha mulé, vai procurar teus direito. Depois tu volta pra fazer teu café; depois tu volta pra fazer teu café... Vai procurar teus direito, mulé" (MERCÊS, 2010). Esta frase musical que está registrada no material iconográfico e que faz parte do repertório musical de Dona Maria Baia, apresenta-se como um exemplo de fissura, ruptura, na condição que é muitas vezes prescrita para essas mulheres sertanejas que estão submissas ao patriarcado rural ainda vigente. Essa e outras cerca de 10 composições que estão na mesma esteira da contraposição ao machismo, fazem parte das mais de 100 composições de Maria Baia e suas companheiras do Grupo Rosas Vivas.

Anu. Lit., Florianópolis, v. 24, n. 1, p. 52-69, 2019. ISSNe 2175-7917 
Remete-nos a um claro chamamento desta mulher que está na lida doméstica, na lida no campo, na criação dos filhos e que, além disso, tem que acordar cedo para cuidar do alimento da família e, com isso, pode não se dar conta da sua condição feminina. Entretanto ela se dá conta. Ela canta e evoca um movimento feminino/feminista de deslocamento da sua função/condição de "dona-de-casa" e estimula uma ruptura com o silenciamento e a subalternidade.

Michel Foucault (1996), em $A$ ordem do Discurso, denuncia os "modos de seleção e exclusão" que estão presentes em nossa sociedade. Dessa forma, alerta e chama a atenção para o fato de que não é qualquer pessoa, em qualquer lugar, que pode falar qualquer coisa. Trata-se de mecanismos de interditos, que realçam a anulação, o silenciamento, em nosso contexto aqui tratado, da voz feminina e do sujeito mulher que se atreve a escrever uma outra história para si (FOUCAULT, 1996).

Temos subscrito aqui um lugar e movimento de fala contraposto à "normalização" da condição feminina prevista pelo machismo patriarcal, em sua forma de literatura, que muitos podem considerar como uma "literatura menor", entretanto esta apresenta linguagens e linguajamentos, engendramentos em narrativas e cronismos que sugerem uma espécie de ato político, de "subversão coletiva transitiva"; que está contraposta às condições impositivas de exclusão e discriminação social deste coletivo de pessoas, especialmente estas mulheres, que estão assujeitadas.

Deleuze e Guattari (1997), preconizam que esse tipo de "literatura menor" possibilita uma nova produção narrativa, que apresenta uma linguagem que redimensiona a língua estabelecida e conservada pelos grupos dirigentes, uma linguagem ativa e revolucionária do ponto de vista criativo. Segundo os autores, trata-se do momento em que a linguagem não é definida pelo que dizemos e muito pelo que dá significado a ela, todavia, ela é condutora de um fluxo que faz fluir e explodir o desejo (DELEUZE; GUATTARI, 1997).

Percebemos que a subjetividade, latente e presente nas narrativas musicais, possibilitam a Dona Maria Baia processos de construção da sua autopercepção de mulher, empoderada, que denuncia aspectos da subalternidade feminina e de menos valia que estão arraigados a subjugação feminina interposta no e pelo patriarcado, ainda hegemônico em nossa sociedade e, certamente, mais evidente e recorrente nas comunidades campesinas, onde nossa personagem está inserida.

Neste contexto, podemos traçar um paralelo com escritos da professora e pesquisadora Jailma Moreira (2015) a qual relata uma experiência, descrita em um dos seus artigos, no qual retrata uma vivência pessoal junto a autoras negras e outras mulheres escritoras de AlagoinhasBA. A pesquisadora, a partir das narrativas feitas em uma mesa redonda com escritoras, em Seminário do GT da Anpoll, ${ }^{8}$ Mulher e Literatura, realizado no campus da UnB em 2011, cita a fala de uma delas, Geni Guimarães, que, em situação de "menos valia" e em conflito na convivência doméstica com seu esposo e censor, escrevia e se reescrevia, apesar da negação

\footnotetext{
${ }^{8}$ Associação Nacional de Pós-Graduação e Pesquisa em Letras e Linguística (ANPOLL).
} 
introjetada por muitas mulheres do perfil de produtora textual (MOREIRA, 2015). Há verossimilhança com a condição de Maria Baia, inclusive por não se perceber, inicialmente, enquanto escritora de si. Moreira descreve que:

[...] a dificuldade da autopercepção da possibilidade de ser outra ou, no caso de Geni, de levar adiante essa percepção diferencial de si deriva da relação de forças entre o se ver e o ser visto. Ou seja, não foi à toa que mulheres introjetaram uma imagem de si como não-escritoras, visto que não foi esse o papel predestinado a elas. Pelo contrário, a cultura patriarcal e capitalista as destinou ao campo da reprodução, tornando cada vez mais invisível sua força produtiva, nos moldes de uma exploração, daí a dificuldade de esse sujeito feminino se conceber como produtor textual. (MOREIRA, 2015, p. 75)

Considerando uma produção literária não canônica, ou mesmo uma produção textual ampliada, a professora Jailma Moreira cita Virginia Woolf (1985) com seu livro Um teto todo seu, conclama para a inevitabilidade da mulher construir e consolidar um espaço e tempo, para produzir e escrever contudo, há obrigações em seu cotidiano que foram historicamente constituídas e que se apresentam enquanto impeditivos e dificultam esse produzir bem como, a desvalorizam como produtora (MOREIRA, 2015).

Maria Baia tem avançado muito em suas escrevências, culinária alternativa, artesanatos e cantorias com o Rosas Vivas. Já se reconhece como literata e produtora de cultura popular e, essa percepção, está viva e pulsante em sua atual constatação que se contrapõe a uma percepção inicial, ou anterior de si, como um "ser menor" - desvalidado. Como uma das articuladoras e fundadora do Grupo de Cantorias Rosas Vivas, tem colocado sua potência criativa na composição da maioria das músicas do Grupo e, sem dúvida alguma, este movimento de evocação de subjetividades latentes vêm contribuindo para uma outra percepção e relocação de si. Segundo ela:

[...] Eu me sinto feliz. Muito feliz. Às vezes quando eu ouço o CD assim tocando nas casas vizinhas, é muita emoção, eu chego às vezes até a chorar. Porque a gente olhando lá trás, o antes, até lá trás, a gente imagina assim, “quem era eu?", eu me pergunto assim, “quem era eu?", eu não era ninguém. $\mathrm{Na}$ minha concepção viu? Eu fico perguntando, "quem era eu? Eu não era ninguém". Porque hoje eu sou vista no mundo [...] (MERCÊS, 2017a).

No repertório musical do Rosas Vivas e, paralelamente nos outros (a)fazeres artísticos/culturais das mulheres do grupo, trazem o registro iconográfico de superações femininas, falam delas e para outras(os), através de várias narrativas e poéticas simbólicas que expõem linguagens, signos e significantes que denunciam a condição da mulher oprimida que é muitas vezes subjugada pelo homem. Retratam nuances performáticas de uma realidade imagética, de um ideal projetado, que horizontalizam relações interpessoais como também evocam um modo de vida peculiar ao cotidiano de labutas das populações campesinas da região sisaleira.

No sentido da linguagem e signos mais uma vez o crítico cultual Osmar Moreira Santos (2010) traz um olhar e contribuição ao afirmar: 
[...] Todo sujeito acontece na linguagem e com a linguagem. Acontecer na linguagem, enquanto sujeito, é se dá conta de que consumimos signos [...] Os signos que consumimos podem nos consumir ou serem re-elaborados e constituírem a performance de cada um enquanto criadores e/ou reprodutores de realidades. (SANTOS, 2010, p. 122-123)

$\mathrm{Na}$ linguagem falada em vários idiomas e semantismos; na escrita e outras escrituras; nos signos e significantes é que Mignolo (2003) circunscreve à ideia da (re)locação do linguajamento, enquanto "o lócus onde ocorre a conscientização", sob a forma de luta e de uma transcendência da linguagem cânone para uma forma particular de alívio de tensões; no sentido de romper com a opressão colonialista que a língua pode impor e inferir. Daí o rompimento com uma estética linguística verticalizada e hierarquizada e, que, permite o entendimento para além da língua e suas formalidades; "torna-se um ato de amor e um anseio de superação do sistema de valores como forma de dominação" (MIGNOLO, 2003, p. 309).

O multifacetamento da nossa personagem central aponta para uma visão de um linguajamento refinado, bilinguajado, engendrados nos processos contínuos de criação de signos, de significantes, de circulação e de consumo. No movimento cultural do Rose, há uma vertente empoderativa de (a)fazeres que possibilitam uma maior e melhor apropriação e preservação das tradições da cultura popular campesina. Intervêm na melhoria das relações interpessoais, psicoafetivas, socioeducativas e na preservação da memória coletiva na qual crianças, jovens, adultos e idosos estão imersos! (INSTITUTO, 2007).

\section{Interseccionalidade e ato político}

Nossa personagem central imbrica provocações e resistências, através de letras, versos e poéticas que vêm inspirando e despertando outras mulheres contra as prescrições exercidas pelo patriarcado. Em outra das suas composições, que faz parte do repertório dos Rosas Vivas, diz: A mulher é companheira; A mulher não é escrava; A mulher não é tapete para ser pisada; A mulher tem o direito; O mesmo que o homem tem; Não tenha medo de nada; Venha participar também" (INSTITUTO, 2017).

Neste registro narrativo há uma convocação, um chamamento, para uma rota de enfrentamento que evoca possibilidades de um outro modo de vida, uma outra percepção de si, que se desenha enquanto a possibilidade de um "ser feminino" de resistências, frente às condições adversas e a interseccionalidade ${ }^{9}$ que, exclusivamente, penalizam e assujeitam essas mulheres campesinas a uma condição de "menos valia." A interseccionalidade impõe uma repressão aditiva, sexista, neste caso em que tratamos de dona Maria Baia e, de certa forma, por extensão, do grupo de mulheres Rosas Vivas, repressão multiplicada pelas marcas da intersecção de gênero, classe etc. Ou seja, de forma mais simples podemos dizer que estas

\footnotetext{
${ }^{9} \mathrm{O}$ conceito de "interseccionalidade" foi batizado desta maneira por Kimberlé Williams Crenshaw, professora especializada nas questões de raça e de gênero. Termo pela primeira vez usado numa pesquisa, em 1991, sobre as violências vividas pelas mulheres de cores nas classes desfavorecidas nos Estados Unidos. Consiste em "formas de capturar as consequências da interação entre duas ou mais formas de subordinação: sexismo, racismo, patriarcalismo.”. Fonte: http://www.sociologia.com.br/o-conceito-de-interseccionalidade/. Acesso em: $28 / 07 / 2018$
} 
mulheres sofrem com a exclusão por serem mulheres, agricultoras, pobres, negras e assentadas.

Neste sentido, Chimamanda Adichie (2014) aborda essa questão de gênero e feminismo, problematizando a questão em relação aos direitos humanos, universais, afirmando que, no processo de legitimar direitos humanos, é necessário que se alerte e ressalte de que, o feminismo, certamente, está inserido nos direitos humanos dentro de uma perspectiva geral contudo, ao escolher e jogar luz exclusivamente na expressão 'direitos humanos' pode estar se negando particularidades e especificidades que estão contidas nas questões e problemas de gênero (ADICHIE, 2014).

Então, lançar um olhar não atento para a questão da interseccionalidade, e sua forma subliminar, pode submeter o ser feminino ao direito universal, genérico, sem atentar para as singularidades de gênero e suas intersecções, que impõem às mulheres situações adversas, as quais os homens não estão submetidos. Adichie salienta que, "feminista" pode ser o homem ou a mulher que afirma e pontua que há sim um problema de gênero e, que, é preciso que ainda hoje precisamos resolvê-lo, para que todos nós, homens e mulheres, melhoremos enquanto humanos. Reforça que não é a cultura que faz as pessoas, mas, sim, o contrário: pessoas é que fazem a cultura. Sendo assim, se uma humanidade inteira de mulheres não faz parte da cultura, então temos que mudar nossa cultura (ADICHIE, 2014).

As manifestações performáticas, inscritas na cultura popular, evidenciadas por Maria Baia, por certo agenciam ações empoderativas no Grupo Rosas Vivas, que indicam um movimento de colisão interseccional, contraposições aos ditames patriarcais, sexistas, que ainda estão bem presentes e delineados no universo de um Brasil rural, machista e opressor. A poética das letras de Maria Baia podem até parecer despretensiosas, podem parecer, contudo, há mensagens diretas e subliminares que agregam vocativos que lançam um deslocamento, rotas de enfrentamentos, que legitimam um lugar de fala feminina que se desenha enquanto um campo de resistência às condições adversas de subalternidade, as quais estão expostas no seu habitat social.

Fica delineado que existe em andamento todo um processo de rupturas e resistências que está bem pontuado na letra ora descrita, pois parte dela reivindica: “(...) A mulher tem o direito; O mesmo que o homem tem; Não tenha medo de nada; Venha participar também" (INSTITUTO, 2017). Esse chamamento coletivo circunscreve um ato performático e de manifestação cultural, literária, através de dona Maria Baia, compositora e cantora, que sugere estar se colocando diante de outras mulheres, conclamando outras mulheres para se apropriar da ruptura e deslocamento do patriarcado, que as resguardou a uma condição de menor representatividade.

Esses afazeres poéticos, esse discurso político-social de dona Maria Baia foi engendrado ou fortalecido à medida em que ela se engajou com um coletivo de pessoas em função das demandas comuns à todos, esteve, portanto com os outros na construção de um território agenciador de possibilidades empoderativas. Nesse movimento o fazer cultural se interrelacionava, o canto se entremeava, a comida traduzia uma fome. Assim, o fazer cultural se transfigura em um ato político e de resistência, individual e coletiva, que está reinventando

Anu. Lit., Florianópolis, v. 24, n. 1, p. 52-69, 2019. ISSNe 2175-7917 
sujeitos, reorganizando grupos, dia após dia, tendo em vista a aridez e o desfavorecimento das relações hierarquizadas, subalternizadas, predominantes em muitos rincões do Brasil.

Sobre este fazer cultural enquanto ato político, Stuart Hall (1999) pontua e chama a atenção para um olhar mais aguçado do pesquisador, quando salienta que a cultura popular é um campo, um local, de engajamento para a luta a favor ou contra a cultura dos poderosos e é também o prêmio a ser conquistado ou perdido nessa luta. Trata-se de uma arena de resistência e do consentimento. Contexto e lócus em que o socialismo ou uma cultura socialista, formatada, simplesmente pode ser manifesta e expressada (HALL, 1999).

\section{Um lugar de resistências, inspiração e subjetividades}

Para falar de lugar de luta, resistências, subjetivação e engajamento é essencial retomar um ponto de mutação na história de dona Maria Baia, que foi a fixação de moradia sua, da sua família e dos seus companheiros no assentamento Rose, conseguido através da luta pela posse e conquista da terra. $\mathrm{O}$ assentamento Rose se apresenta enquanto lugar de chegada e ponto de partida para outros lugares. Lugar que agrega significâncias difusas, tendo como pano-de-fundo inicial a conquista da terra, de um chão para fincar raízes.

Mercês (2017a) descreve o enfrentamento de vários obstáculos, que constituíram a disputa com os latifundiários, donos da então fazenda Lagoa do Boi, em Santa Luz- Bahia. Desta época de luta e "ocupação da ocupação" da terra ela relata com orgulho esse momento:

[...] tinha terra lá que era da "Cabrine" (na realidade Klabin Celulose), aí os sindicatos se reuniram, juntou o pessoal e acamparam a terra; lá era desta mineradora... Ah durou anos. Foi na faixa de 3 anos! (...) A moradia era barraca de lona. Eu dormia com 9 filhos debaixo (...) De dia era calor que ninguém aguentava, de noite era frio que pingava água no chão da lona. Muito sofrimento viu?. Rapaz! Isso aí foi muito sofrimento. Porque assim, eu tinha muita criança, aí eu tinha que trabalhar, para cuidar das crianças e de noite às vezes quando vinha chuva, eu tinha que ficar, servir de morão, para suspender a lona. (...) Para a lona não encher de água e não estourar em cima dos meninos. Muitas e muitas vezes, de noite, passei assim (...) E aí o governo veio e desapropriou e hoje nós estamos lá...28 anos morando lá! (MERCÊS, 2017b)

Deste momento, a composição "Pé no chão" de Maria Baia, gravada no $1^{\circ} \mathrm{CD}$ do Grupo Rosas Vivas (INSTITUTO, 2010), descreve em seus versos, de forma sutil e com mensagens subliminares, a percepção deste momento de luta pela terra e enfrentamentos com os "senhores latifundiários - donos da terra". Os versos curtos e cantados repetidamente como mantra, expõem uma forma de relação de poder que delimita fronteiras e papeis entre as classes: dominante (grandes latifundiários) e camponesa e trabalhadora (subalterna). Diz a letra:

Quando eu cheguei no Rose;

cheguei de pé no chão.

Pra falar com marajá, foi só de avião, foi só de avião.

Pra falar com marajá, foi só de avião

Só de avião, 
Pra falar com marajá, só de avião (INSTITUTO, 2010).

A figura do marajá faz referência ao senhor de poder que na Índia feudal era um título dado aos príncipes e que hoje o título é meramente honorífico. Aqui no Brasil, simbolicamente, alude distinção entre a pessoa que conquistou riqueza, de forma a explorar a força de trabalho alheio edificando riqueza com a miséria e exploração alheia. $O$ termo também pode ser aludido aquele funcionário público ou de empresa pública, cujo salário e demais vantagens são exorbitantemente altos. No sertão essa figura representa o "coronel”, ou seus herdeiros, que são os "donos" da terra, que ocuparam um espaço coletivo, e estabeleceram um poder expropriador e dos meios de produção. Juntar-se como o outro, com outros subalternizados e aviltados da condição de ser humano, ser de direitos a um chão, a terra para plantar, colher, viver e existir dignamente juntos com seus iguais, encontra eco e sentido no pensamento do professor e crítico cultural Osmar Moreira Santos (2016), quando fala da luta dos subalternos:

[...] sua forma de luta e seus modos de enunciação são singulares e respondem a uma dobra do poder, como acontecimento: confronta o chefe local, expõe representantes do sistema de poder (a cada instância que interpela e supera em sua vontade de justiça), mobiliza seus parcos recursos de camponeses pobres... [...] ativa sua sensibilidade e inteligência, à medida em que os desafios vão se colocando durante seu processo de luta e enfrentamento (SANTOS, 2016. p. $61)$.

Em um ponto de análise, e sem deixar de lado o sentido de unicidade dialógica, o "cheguei de pé no chão", em contraponto ao sentido de marajá presente no contexto, pode ser entendido imageticamente também como uma certeza, uma segurança de objetivo, de estar fincando o pé no chão. Certeza do que se quer ter, do que se pretende ser, enquanto um ser individual que se agrega a um coletivo de outros indivíduos com desejos e um discurso em comum: o de apoderarse, o de ter poder, fortalecer o desejo sobre algo pelo qual se luta com afinco, na certeza de dias melhores.

Um outro desdobramento dessa interpretação seria perceber o deslocamento da frase "cheguei de pé no chão" para um possível entendimento de que ao fincar o pé no chão se estaria firmando que esse lugar pertence a quem luta e precisa de um pedaço de chão para sobreviver. Este coletivo de pessoas do movimento pela posse da Fazenda Lagoa do Boi desenvolveu o que estamos chamando de "ocupação da ocupação", visto que estariam reocupando aquele espaço que anteriormente era de todos, era dos nativos, habitantes da terra que depois fora colonizada, dividida e atribuída a alguns poucos donatários. Movimento que busca ter de volta para o coletivo um direito que deve ser universal: o direito à terra para produzir e sobreviver dignamente. Movimento que busca fazer valer esse direito.

Foucault (1996), em A Ordem do Discurso, discorre sobre o significado do discurso apontando que ele não é a tradução simples das lutas ou sistemas de dominação contudo, por certo, é a tradução daquilo que motiva e se configura em algo pelo qual se luta, ou seja, o poder sobre o que queremos apoderar. Prossegue inferindo que os processos de interdições que afetam o discurso o ligam ao desejo e ao poder. 
Neste aspecto a música "Pés no chão" do CD de cantoria do Rosas Vivas, composição de Maria Baia, pode ser alinhada com esse desejo de poder, de apoderamento, em que a vontade dos sujeitos de ter seu pedaço de terra; de ter um sonho de vida digna realizado; de construir sua história e de ter um lugar/espaço de fala reconhecido e respeitado, é a concretização de aspectos motivacionais que agregam indivíduos ao seu desejo e superação interditos estabelecidos por um dominador que expropria esse direito, no caso da letra, o "marajá", o senhor detentor do poder a ser destituído.

Considerando a experiência gregária de pessoas no processo de consolidação da comunidade Rose, Augusto Boal (2009) nos diz que o ajuntamento, o "face-a-face", o encontro entre homens é subliminarmente identificado como sendo de uma "estética gregária", em que se tratam da reelaboração e ressignificação do imagético, da arte da palavra falada que encanta e evoca o simbólico, dando significados empoderativos. Em seu livro, Estética do Oprimido, diz não pode ser vazia e inocente nenhuma estrutura de arte, haja vista que todas elas abrigam uma visão de mundo de quem abriga e produz sua ideologia. Trata-se de um mecanismo que por vezes estabelece um diálogo antagônico, através do qual todos podem se encontrar e buscar soluções individuais e coletivas; formas conscientes e inconscientes de opressão (BOAL, 2009).

$\mathrm{Na}$ perspectiva do inconsciente, das singularidades de pessoas e lugares que inspiram subjetividades e a criação, os (re)cantos de Baia, com seus cheiros, cores, contrastes e forças etéreas da natureza evocam e sugestionam o acesso a um universo mágico, que ilumina o potencial criativo, as criações dos versos e melodias da autora. Especialmente a natureza exerce um fascínio inspirador sobre Baia, que relata:

[...] a inspiração de uma música, assim, eu não tenho palavras, eu não sei como vem. Porque quando eu saio para pegar algum cacto, às vezes até um (embu) que às vezes a gente panha, aí vem a música. Aí eu vejo lá uma planta, uma flor, uma árvore, e aí me vem a letra, eu não sei explicar da onde vem. Não é um caso, não é uma coisa que eu vou planejar, que eu vô tá cantando letra por letra, para formar uma música, não, vem (...) vem toda e aí eu começo a... começo do começo do princípio e aí com um exemplo, do pé de carrancudo, quer dizer, eu fui no mato e lá eu vi aquele pé, e daí me veio a letra. (CANTA): "Andando na catinga me diga que flor mais cheira, quando nas primeiras águas carrancuda é quem mais cheira. Carrancuda é quem mais cheira nas caatingas nordestinas, vamos acordar para ver a beleza na caatinga". Então, esse carrancudo, ele é uma árvore que só flora quando chove trovoada, as primeiras águas. (MERCÊS, 2017b)

O caráter imagético subscrito neste depoimento de Baia indica a presença de outras representações, de divindades inspiradoras, que se apresentam enquanto forças da natureza, forças que a inspiram a criar. A natureza, como relata, é percebida como algo que a envolve, que a arrebata e a conecta a um estado de "consciência alterada" no qual ela mergulha e se "deixa conduzir". A subjetividade é presentificada no momento de um aqui-agora, em que o contato com a natureza faz eclodir a inspiração, a singularidade criativa.

A este aspecto da subjetividade, da não consciência da súbita inspiração de Baia, a teoria da psicologia analítica de Jung (2011) afirma que possuímos 2 tipos de inconsciente: pessoal e

Anu. Lit., Florianópolis, v. 24, n. 1, p. 52-69, 2019. ISSNe 2175-7917 
o impessoal este, também denominado de suprapessoal. Este último é representado pelo que muitos já conhecem ou ouviram falar como inconsciente coletivo ${ }^{10}$ que é desligado do pessoal por ser ligado totalmente ao universal. Ou seja, por seus conteúdos existirem por toda parte tem sua origem nos processos de ancestralidade sociocultural da humanidade. Os conteúdos do inconsciente pessoal são mais acessíveis por estarem em uma camada do inconsciente mais próxima da consciência (JUNG, 2011).

Os conteúdos do inconsciente coletivo também estão permeados pelos arquétipos em que o conjunto de imagens e representações sociais colaboram para a satisfação de algumas das nossas principais necessidades como a de (a)filiação e pertença a um determinado grupo ou instituição social; de autorrealização; de independência ou de até influenciar no consumo de produtos e serviços: de produzir o desejo, a subjetividade, de fora para dentro, que estão presentes na sociedade (auto)consumista capitalista: grandes "vendedores de desejos".

Sobre essa perspectiva da subjetividade, Guattari e Rolnik (1996) já nos trazem um outro olhar que aprofunda e amplia essa ideia da subjetividade produzida como um produto de consumo. Segundo eles:

[...] Tudo que é produzido pela subjetivação capitalista - tudo que chega pela imagem, pela família e pelos equipamentos que nos rodeiam - não é apenas uma questão de ideia, não é apenas uma transmissão de significações por meio de enunciados significantes [...] Trata-se de um sistema de conexão direta entre grandes máquinas produtivas, as grandes máquinas de controle social e as instâncias psíquicas que definem a maneira de perceber o mundo. (GUATTARI; ROLNIK, 1996, p. 27)

Mas como localizar nossa personagem central, Dona Maria Baia, neste estudo dialógico e encontrar conectivos da produção subjetiva descrita nos processos de inspiração dela? O que de fato pode revelar estar neste contexto, lugar de criação em que se manifestam subjetivismos em profusão sensoriais e perceptivos? Ainda estamos buscando alinhar constructos investigativos e de aprofundamento desta pesquisa, para consubstanciar engendramentos que possam discutir esses processos subjetivos. Como ela mesma afirma em um trecho da sua entrevista descrita acima: "[...] eu não sei explicar de onde vem. Não é um caso, não é uma coisa que eu vou planejar, que eu vô tá cantando letra por letra, para formar uma música, é um algo que acontece fora de mim..." (MERCÊS, 2017b).

A priori podemos identificar e sugerir uma evidência arquetípica presente nas narrativas dela, quer seja através dos mitos, histórias, personagens (reais e imaginários); quer seja também através de um desejo de produzir signos e significantes que possam dar forma ao seu imaginário e, a partir desta produção subjetiva (presenteísmo do imaginário), consciente e-ou inconsciente, encena desejo de ser validada, reconhecida e conquistar o respeito e admiração de seus pares e estabelecer um lugar/espaço de fala de fato e de direito.

\footnotetext{
${ }^{10}$ Para psicologia analítica de Jung, o inconsciente coletivo não se desenvolve individualmente, ele é herdado. É um conjunto de sentimentos, pensamentos e lembranças compartilhadas por toda a humanidade. É um reservatório de imagens em que os arquétipos (símbolos, imagens ou sentimentos que agregam significados e significâncias universais e que, a humanidade vem acumulando secularmente) são abrigados (JUNG, 1991).
}

Anu. Lit., Florianópolis, v. 24, n. 1, p. 52-69, 2019. ISSNe 2175-7917 
Sendo assim, o pé no chão de dona Maria Baia, o seu andar em meio a caatinga que lhe inspira, traduz-se em outras rotas, outras trilhas sertanejas, outros modos de vida, potencializados com a ocupação da ocupação do Assentamento Rose. E agora, com este estudo sobre Maria Baia, podemos dizer, que se transfigura em uma reocupaçaão desta ocupação da ocupação, visto que a mulher, as sertanejas, na voz de Baia, reivindicam um outro lugar nessa história, constroem, cantam uma outra história de si.

Retomando a fala de Maria Baia, logo lá no início deste texto, ela reescreve uma outra percepção de si quando finaliza seu pensamento autoperceptivo: “...Hoje as pessoas me olham com outro olho. De admiração! Sou muito cortejada... Mais respeitada!. As pessoas me ouvem mais. Aí diz: “não, dona Maria falou, é assim” Antes não era assim!” (MERCÊS, 2017b).

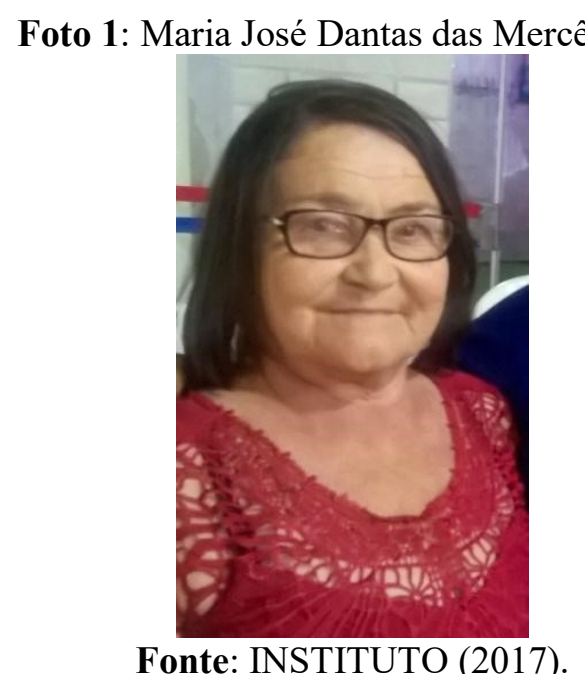

\section{Considerações finais}

Percebemos que no transcorrer da vida de Maria José Dantas das Mercês, Dona Maria Baia, até então, há uma narrativa que sugere uma trajetória de vida que foi se construindo, um ser mulher que aos poucos foi se moldando e se fortalecendo, à medida que houve uma interação com outras pessoas, que se estabeleceu relações de valores e de trocas que consubstanciaram um exercício compartilhado de percepções, sentimentos, afetos, cognições e pensamentos que, possivelmente, enriqueceram as relações dela consigo mesma e com o outro.

Através da sua história de vida, aqui em um breve registro biográfico, também reconhecemos uma inquietação precoce de uma menina, mais tarde uma senhora, que fez escolhas por caminhos e chamamentos que promoveram elementos introspectivos que foram se consolidando e se "ajustando" aos desafios e obstáculos que o contexto impõe às mulheres e aos homens também.

Nesta perspectiva, há indicativos que sua experiência de vida e os seus modos de produção das letras, de outras letras, agenciam elementos enriquecedores e potencializadores, através dos quais Dona Maria Baia expressa esta percepção existencial e ao mesmo tempo se vê impulsionada para a (re)descoberta de uma consciência de mundo, não ingênua, que vem desafiando os silenciadores e as formas de interdição da sua potência humana criativa. 
Para esta arte do (re)encontro com o outro e consigo mesmo, Martin Buber (2001), em sua obra Eu-Tu, afirma que o ato do encontro com o outro é uma celebração essencial para a reciprocidade e para a troca de experiências e conhecimento; vital à ontologia humana e que tem no "face-a-face" a validação da existência e validação do ser, "do eu em você e você em mim". Uma frase que talvez ilustre bem tudo isso é: "toda a verdadeira vida é encontro" (BUBER, 2001). Nesse contexto, em que tratamos do encontro de dona Maria Baia com o movimento de ocupação da terra, com o grupo de mulheres Rosas Vivas, com a caatinga enquanto vegetação resistente do sertão, podemos dizer que o que mais queremos destacar seja esse reencontro dessa menina-mulher-senhora com a outra que sempre poderá ser, fora dos ditames patriarcais. Encontro com a escrita de vida criativa, com a possibilidade, sempre desenhada, de escrever outros caminhos para si.

\section{Referências}

ADICHIE, Chimamanda Ngozi. Sejamos todos feministas. São Paulo: Companhia das Letras, 2014.

BOAL, Augusto. A Estética do oprimido. Rio de Janeiro: Garamond, 2009.

BUBER, Martin. Eu e Tu. Tradução do alemão, introdução e notas por Newton Aquiles Von Zuben. 10. ed. São Paulo: Centauro, 2001.

DELEUZE, Gilles; GUATTARI, Félix. Kafka: por uma literatura menor. Rio de Janeiro: Imago, 1977.

FOUCAULT, Michel. A Ordem do Discurso. São Paulo: Edições Loyola, 1996.

GUATTARI, Félix; ROLNIK, Suely. Cartografias do desejo. Petrópolis - RJ: Vozes, 1996.

HALL, Stuart. Da diáspora: identidades e mediações culturais. Trad. de Adelaine La Guardia Resende. Belo Horizonte: Editora UFMG, 1999.

HALBWACHS, Maurice. A memória coletiva. 2. ed. São Paulo: Editora Revista dos Tribunais, 1990.

INSTITUTO MARIA QUITÉRIA (Brasil). Acervo e Memorial Iconográfico Grupo Rosas Vivas (fotos, vídeos, entrevistas e transcrições) - Cantoria Popular de Mulheres da Comunidade do Rose. Feira de Santana, BA: IMAQ, 2017.

INSTITUTO MARIA QUITÉRIA (Brasil). CD Rosas Vivas: Grupo de Cantoria Popular de Mulheres da Comunidade do Rose. Selo Cultural Cabeça-de-frade. Santaluz, BA: IMAQ, 2010.

INSTITUTO MARIA QUITÉRIA (Brasil). Projeto Griôs Sisaleiros. Feira de Santana, BA: IMAQ, 2007.

JUNG, Carl Gustav. A Natureza da Psique. 2. ed. Petrópolis: Vozes, 1991.

JUNG, Carl Gustav. Psicologia do inconsciente. 19. ed. Petrópolis: Vozes, 2011. 
MERCÊS, Maria José Dantas das. Cabeça de frade faz doce: as cantigas e a culinária de Dona Maria Baia. Feira de Santana, BA: IMAQ, 2010.

MERCÊS, Maria José Dantas das. Entrevista gravada em aparelho celular, modelo Motorola. Assentamento Rose, Santa Luz-BA. (Entrevista concedida a Edisvânio do Nascimento Pereira em 27/03/2017.). Acervo e Memorial Iconográfico Grupo Rosas Vivas (entrevistas e transcrições). Acervo e Memorial Iconográfico Grupo Rosas Vivas (entrevistas e transcrições). Feira de Santana-BA: IMAQ, 2017a.

MERCÊS, Maria José Dantas das. Entrevista gravada em aparelho celular, modelo Nokia 630. Feira de Santana-BA. (Entrevista concedida a José Luiz da Silva Lima em 27/07/2017). Acervo e Memorial Iconográfico Grupo Rosas Vivas (entrevistas e transcrições), Feira de Santana-BA: IMAQ, $2017 b$.

MIGNOLO, Walter. Histórias locais / Projetos globais: colonialidade, saberes subalternos e pensamento liminar. Belo Horizonte: UFMG, 2003.

MOREIRA, Jailma dos Santos Pedreira. Reescrita de si: produções de escritoras subalternizadas em contexto de políticas culturais. Revista Fórum de Literatura Brasileira Contemporânea, v. 7, n. 13, p. 71-88, 2015.

SANTOS, Osmar Moreira dos. Um Oswald de bolso: crítica cultural ao alcance de todos. Salvador: UNEB, Quarteto, 2010.

SANTOS, Osmar Moreira dos. A luta desarmada dos subalternos. Belo Horizonte: UFMG, 2016.

WINNICOTT, Donald Woods. Distorção do ego em termos de verdadeiro e falso self. In: WINNICOTT, Donald Woods. Ambiente e os processos de maturação: estudos sobre a teoria do desenvolvimento emocional. Porto Alegre: Artmed, 1983.

WOOLF, Virginia. Um teto todo seu. Rio de Janeiro: Nova Fronteira, 1985.

José Luiz da Silva Lima (joseluizlima.imaq@gmail.com) é mestrando (Edital 092/2017) do Programa de Pós-graduação em Crítica Cultural, nível de Mestrado, da grande área de Linguística, Letras e Artes da Universidade do Estado da Bahia - UNEB, Campus II / Alagoinhas. Pós-graduado em Docência do Ensino Superior pela Uniasselvi (2016.1). Graduado em Psicologia pela Faculdade de Tecnologia e Ciências - FTC-FSA (2015.2).

Jailma dos Santos Pedreira Moreira (jailmapedreira@uol.com.br) possui Graduação em Letras Vernáculas pela Universidade do Estado da Bahia - UNEB (1996), uma Especialização em Texto e gramática pela Universidade estadual de Feira de Santana - UEFS - em convênio com a UNICAMP (1999), outra em Estudos Literários pela UNEB (2000), Mestrado em Letras e Linguística pela Universidade Federal da Bahia - UFBA (2003) e Doutorado também na área de Letras nesta última universidade (2008). Concluiu pós doutorado em Letras - metacrítica feminista|Políticas públicas para a literatura feminina- na UFMG(2015). 


\section{NOTAS DE AUTORIA}

Como citar esse artigo de acordo com as normas da revista

LIMA, José Luiz da Silva; PEDREIRA, Jailma dos Santos. Dona Maria Baia: uma escritora de si. Anuário de Literatura, Florianópolis, v. 24, n. 1, p. 52-69, 2019.

\section{Contribuição de autoria}

José Luiz da Silva Lima: coleta e análise de dados, elaboração do manuscrito, da redação e discussão final dos resultados.

Jailma dos Santos Pedreira Moreira: análise de dados, orientação na elaboração do manuscrito, redação e discussão de resultados.

\section{Financiamento}

Não se aplica.

\section{Consentimento de uso de imagem}

Registro fotográfico realizado por José Luiz Lima com a autorização de Maria José Dantas das Mercês.

Aprovação de comitê de ética em pesquisa

Não se aplica.

\section{Licença de uso}

Este artigo está licenciado sob a Licença Creative Commons CC-BY. Com essa licença você pode compartilhar, adaptar, criar para qualquer fim, desde que atribua a autoria da obra.

\section{Histórico}

Recebido em: 14/03/2019

Aprovado em: 14/06/2019

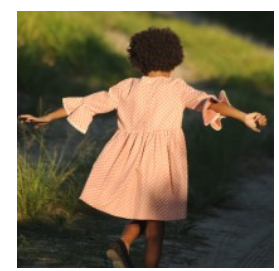

